\title{
Defining the Delta Virus Positivity in Hepatitis B Virus Infections
}

\author{
Hepatit B Virüs Enfeksiyonlarında Delta Virüs Pozitifliğinin Belirlenmesi
}

\author{
Adil KARADAĞ1, Hava YILMAZ2, Ibrahim GÖREN3, Ibrahim Çağatay ACUNER4, Cafer EROĞLU1, \\ Murat GÜNAYDIN1 \\ 1 Ondokuz Mayıs University Faculty of Medicine, Department of Medical Microbiology, Samsun, Turkey \\ 2Ondokuz Mayıs University Faculty of Medicine, Department of Clinical Microbiology and Infection Disease, Samsun, Turkey \\ ${ }^{3}$ Ondokuz Mayıs University Faculty of Medicine, Department of Gastroenterology, Samsun, Turkey \\ 4 Yeditepe University Faculty of Medicine, Department of Medical Microbiology, Istanbul, Turkey
}

\begin{abstract}
Objective: The aim of this study was to retrospectively analyze the frequency of anti-hepatitis delta virus (anti-HDV) antibody in hepatitis B virus surface antigen (HBsAg)-positive cases.

Materials and Methods: Anti-HDV and anti-hepatitis B virus core antigen (antiHBc) IgM seropositivity was researched using ELISA method in patients who attended the clinical microbiology laboratory at Ondokuz Mayıs University Medical Faculty Hospital between August 2005 and August 2010 and were determined to be positive for $\mathrm{HBsAg}$.

Results: A total of $2314 \mathrm{HBsAg}$-positive patients were included in this study. AntiHDV positivity was detected in $36(1.56 \%)$ of them. By taking the anti-HBc IgM seropositivity as reference, among patients who had positive delta antibody, 33 $(91.67 \%)$ subjects were evaluated as "super-infection" and $3(8.33 \%)$ patients were evaluated as "co-infection".

Conclusion: Although anti-HDV positivity in our region is relatively lower than in the other regions, emphasis should be given to the prevention and monitoring researches due to the high level of mortality and morbidity of the illness. (Viral Hepatitis Journal 2014; 20(2): 64-66)
\end{abstract}

Key words: Hepatitis B virus, hepatitis D virus, co-infection, super-infection
ÖZET

Amaç: Bu çalışmada retrospektif olarak HBsAg pozitif olgularda Anti-HDV sıklı̆ııın belirlenmesi amaçlanmıştır.

Gereç ve Yöntemler: Çalışmada Ağustos 2005 ve Ağustos 2010 yılları arasında Ondokuz Mayıs Üniversitesi Tıp Fakültesi Hastanesi Klinik Mikrobiyoloji Laboratuvarına müracaat eden ve HBsAg pozitif olduğu tespit edilen hastalarda antiHDV ve Anti-hepatit B kor antijeni (anti-HBc) IgM seropozitifliği ELISA yöntemi ile araştırımışı̧ı.

Bulgular: Çalışmaya toplam 2314 HBsAg pozitif hasta alınmış ve bunların 36'sında $(\% 1,56)$ anti-HDV pozitifliği saptanmıştır. Delta antikoru pozitif olan hastalarda antiHBc IgM seropozitifliği referans alınarak vakaların 33'ü $(\%$ 91,67) süper-enfeksiyon ve 3 'ü $(\% 8,33)$ ko-enfeksiyon olarak değerlendirilmiş̧tir.

Sonuç: Bölgemizde anti-HDV pozitifliği diğer bölgelere göre nispeten düşük olsa da hastalığın mortalite ve morbiditesinin yüksekliği nedeniyle korunma ve izlem çalışmalarına önem verilmelidir. (Viral Hepatit Dergisi 2014; 20(2): 64-66)

Anahtar Kelimeler: Hepatit B virüsü, hepatit D virüsü, ko-enfeksiyon, süper-enfeksiyon

\section{Introduction}

Chronic hepatitis B is one of the most frequent causes of chronic liver diseases and hepatocellular cancer in the world. However, the most important reason of fulminant viral hepatitis is delta virus co-infection or super-infection. Hepatitis delta virus (HDV) is a defective RNA virus $(1,2)$, which can create infections in the presence of Hepatitis B Virus (HBV). Although the infection resources in the society and contagion types are similar with $\mathrm{HBV}$, the distribution and contamination rates in the world are different. It has been assumed that more than $5 \%$ of 300 million hepatitis
B virus surface antigen (HBsAg) carriers, approximately 15 million people, are infected with HDV (3). Regarding the HDV endemicity in the population, four broad classifications of HDV infection have been defined: "very low", "low", "middle" and "high endemicity. Nigeria, Somali, North Uganda, Burundi, Iraq and Turkey were classified as moderately endemic regions $(3,4)$.

Most of the HDV seroprevalance studies, including the ones from our country, have been done either in small or chosen groups. In Turkey, HDV prevalence has been reported in a wide range as $0.9 \%-16.2 \%$ in asymptomatic HBV carriers, $2.5 \%-21.8 \%$ in those with acute HBV infections and $9 \%-51.7 \%$ in patients with 
chronic liver diseases (5). Super-infection with HDV is being more frequently observed in our country with respect to co-infection (1). In this study, we retospectively analyzed the frequency of anti$\mathrm{HDV}$ antibody in HBsAg-positive patients in our region in order to contribute presenting data.

\section{Material and Methods}

Ondokuz Mayıs University Hospital is the most advanced in the province Samsun and its hinterland, serving a total population of ca. 3.665.000. Many patients from the neighboring five cities (namely, Ordu, Tokat, Çorum, Amasya, and Sinop) of the mid-Blacksea region were being admitted to the hospital. Thus, the sampled isolates were representative for the region.

Anti-HDV and anti-HBc IgM seropositivity was researched using ELISA method in patients who attended the clinical microbiology laboratory at Ondokuz Mayıs University Medical Faculty Hospital between August 2005 and August 2010 and were determined to be positive for HBsAg.

Simultaneous HbsAg, Anti-HDV and Anti-HBc IgM positivity is defined as co-infection, whereas simultaneous $\mathrm{HbsAg}$ and AntiHDV positivity with Anti-HBc IgM negativity is defined as superinfection.

\section{Findings}

A total of $2314 \mathrm{HBs} A g$-positive patients were included in this study. Anti-HDV positivity was detected in 36 (1.56\%) of them. By taking anti-HBc IgM seropositivity as reference, 33 (91.67\%) cases were evaluated as "super-infection" and 3 (8.33\%) cases were evaluated as "co-infection" in patients with positive delta antibody. Anti-HDV, anti-HBc IgM positivity ratios, gender distribution, age averages and distribution according to years are presented in (Table 1).

\section{Discussion}

Despite the close relationship between HDV and HBV infections, the association and prevalence of the disease show differences among regions in our country. Although routine HBV vaccination was started in 1998 in Turkey, the prevalence of HDV is still high in East and South East Anatolia, especially in rural areas $(1,6)$. According to the levels of endemicity, generally two different contagion patterns are observed in the world. In high and moderate endemic regions, even though the main route of contagion is not exactly defined, it is claimed that contact with infected blood or bodily fluids, sharing of instruments such as blood contaminated toothbrush and razor blade may have a role (7). Although high prevalence of HDV infection especially in East and Southeast Anatolia is explained by multiple etiologic factors, geographical situation, habits and cultural differences, the exact causes are not known yet (5).

The high prevalence of hepatitis delta in the Eastern and Southeastern part of the country can be attributed to the low socioeconomic status in these regions. HDV prevalence is lowering in native Greeks compared to immigrants, who may contribute $>50 \%$ of the HDV infection burden in Greece (8). Same studies have reported that HDV prevalence in the last 10 years declined in the West, especially in Greece and Italy, and in the Far East (9-11). It is concluded that the rate of HDV infection is lowering and further investigations are needed to validate this finding. This condition can be the result of universal HBV vaccination in the world. However, a recent report have suggested that HDV could be newly introduced into a low endemicity area by immigrants from high endemicity areas, while the epidemological outcome of this type of dynamics would be minor if there is a solid nation-wide protection scheme against HBV in place. $(11,12)$.

Although the prevalence of HDV infection in our country is not exactly known, it has been introduced that it has decreased in the world. This decrease can be related with the general practices to prevent the transmission of HBV as well as hepatitis B vaccination $(9,10)$.

HDV positivity rate detected in this study is (i.e. 1.56\%) lower than those reported from Diyarbakır, Van and Elazığ (i.e. 5.8 to $19.5 \%)$, close to the data introduced from Ankara, Konya and Kayseri (i.e. 1.4 - 5.5\%), Izmir and Manisa (i.e. 3-6.7\%), and Adana and Bursa (i.e. 0.94-5.5\%). Also, HDV positivity rate reported in this study is considered to be lower when compared to overall nationwide rates. (13-15).

Even though a decrease in HDV positivity ratio is being observed in our study, it is not found to be statistically meaningful (Table 1). Further studies with larger sample sizes are needed to investigate the exact reason for this decrease.

Compatible with the results of the previous studies, the prevalence of super-infection in our region is higher than that of co-infection $(1,5)$. We consider that this finding may be due to the high tendency of delta co-infections to become chronic health conditions, and consequently causing an accumulation of patients with super-infections. The accumulation of the patients having super-infection in the society and thus the delta frequency is being increased significantly.

\begin{tabular}{|c|c|c|c|c|c|c|c|c|c|c|}
\hline Year & Case & \multicolumn{2}{|c|}{ Anti HDV (+) } & \multicolumn{2}{|c|}{$\begin{array}{c}\text { Anti-HBc IgM (+) } \\
\text { (co-infection) }\end{array}$} & \multicolumn{2}{|c|}{$\begin{array}{l}\text { Anti-HBc IgM (-) } \\
\text { (super- infection) }\end{array}$} & \multicolumn{2}{|c|}{ Gender } & Mean age (years) \\
\hline 2005 & 168 & 4 & 2.38 & 1 & 25 & 3 & 75 & $3 / 75$ & $1 / 25$ & $50.75(26-65)$ \\
\hline 2006 & 586 & 9 & 1.53 & 1 & 11,11 & 8 & 88.89 & $5 / 55.55$ & $4 / 44.45$ & $42.70(33-55)$ \\
\hline 2007 & 474 & 8 & 1.68 & 0 & 0 & 8 & 100 & $5 / 62.22$ & $3 / 37.78$ & $47.10(31-63)$ \\
\hline 2009 & 418 & 6 & 1.43 & 0 & 0 & 6 & 100 & $4 / 66.66$ & $2 / 33.34$ & $54.30(27-74)$ \\
\hline 2010 & 188 & 2 & 1.06 & 1 & 50 & 1 & 50 & $1 / 50$ & $1 / 50$ & $31.50(16-47)$ \\
\hline Total & 2314 & 36 & 1.56 & 3 & 8.33 & 33 & 91.67 & $22 / 61.22$ & $14 / 38.78$ & $45.63(16-74)$ \\
\hline
\end{tabular}

Note: The findings have been evaluated using chi-square test and it is defined that it is significant when $p<0.05$ 
Besides, detection of co-infection in 3 patients shows that the transmission of delta infection continue to occur in our region.

In line with the literature, despite the fact that no statistically significant difference was detected between the genders, delta positivity was found more frequently in men than in women (1). In this case, the risk of transmission of hepatitis can be explained by the high-risk behaviors among men.

In this study, high average age of patients with HDV positivity (i.e. 45.63 years; $16-74$ years) may indicate that HDV infection is mostly a disease of elderly in the region, while it is less prevalent in the younger population most probably due to the increasingly effective nation-wide vaccination program followed in the last several decades.

Not to detect any positivity in children and teenagers is being considered as a favorable situation for our region.

In conclusion, the seroprevalence of HDV infection is relatively lower in the mid-Blacksea region when compared to previous reports on eastern and south-eastern regions of Turkey. However, continuity of effective protection, vaccination and surveillance programs, both in the region and at the country scale, is necessary to avoid the high morbidity and mortality of the HDV infections.

\section{Conflict of interest: None declared.}

\section{References}

1. Değertekin H, Tabak F, Balık I, Tekeli E. HDV Infeksiyonunun Epidemiyolojisi. Viral Hepatit 2007. 1. Baskı, Istanbul, Viral Hepatitle Savaşım Derneği, 2007: 256-62.

2. Dülger $A C$, Atmaca $M$, Kemik Ö, Küçükoğlu ME, Avcu S. Epidemiologic and Clinical Aspects of Delta Hepatitis in the Van Region. Van Tıp Dergisi. 2010; 17(2): 32-5.

3. Polish LB, Gallagher M, Fields HA, Hadler SC. Delta hepatitis: molecular biology and clinical and epidemiological features. Clin Microbiol Rev. 1993; 6: 211-29.
4. Balık I, Onul M, Tekeli E, Caredda F. Epidemiology and clinical outcome of hepatitis D virus infection in Turkey. Eur J Epidemiol. 1991; 7: 48-54.

5. Bahcecioglu IH, Aygun C, Gozel N, Poyrazoglu OK, Bulut $Y_{\text {, }}$ Yalniz M. Prevalence of hepatitis delta virus (HDV) infection in chronic hepatitis B patients in eastern Turkey: still a serious problem to consider. J Viral Hepat. 2010; 18: 518-24.

6. Hacibektasoğlu A, Barut A, Inal A. Incidence of hepatitis D virus infection in chronic hepatitis B virus carriers. Mikrobiyol Bul. 1992; 26(3): 224-32.

7. Adrian MDB. Viral Hepatitis. Willson RA (ed.) New York: Marcel Dekker Inc; 1997: 217-38.

8. Manesis EK, Vourli G, Dalekos G, Vasiliadis T, Manolaki N, Hounta A, et al. Prevalence and clinical course of hepatitis delta infection in Greece: a 13-year prospective study. J Hepatol. 2013; 59(5): 949-56.

9. Huo TI, Wu JC, Lin RY, Sheng WY, Chang FY, Lee SD. Decreasing hepatitis D virus infection in Taiwan: an analysis of contributory factors. J Gastroenterol Hepatol 1997; 12(11): 747-51.

10. Hadziyannis SJ. Decreasing prevalence of hepatitis D virus infection. J Gastroenterol Hepatol 1997; 12(11): 745-6.

11. Gaeta GB, Stroffolini T, Chiaramonte M, Ascione T, Stornaiuolo G, Lobello S, et al. Chronic hepatitis D: a vanishing disease? An Italian multicenter study. Hepatology. 2000; 32: 824-7.

12. Wedemeyer $H$, Heidrich B, Manns MP. Hepatitis D virus infection-not a vanishing disease in Europe! Hepatology. 2007; 45(5): 1331-2.

13. Cesur S, Kuvat SV, Çiftçi A, Balık I. Kronik Hepatit B Enfeksiyonlu Hastalarda Anti-Hepatit Delta Virüs (anti-HDV) ve Anti-Hepatit C virüs (anti-HCV) antikor sıklığı. Infeksiyon Dergisi. 2003; 17(4): 395-7.

14. Kurtoğlu M G, Üstün C, Bozkurt $H$, Tuncer O, Berktaş $M$. Türkiye'nin Doğusunda Hepatit B Virus Enfeksiyon Dönemlerinde Saptanan Hepatit D Virus Seroprevalansı. Viral Hepatit Dergisi. 2009; 14(1): 27-32.

15. Celen MK, Ayaz C, Hosoglu S, Geyik MF, Ulug M. Anti-hepatitis delta virus seroprevalence and risk factors in patients with hepatitis B in Southeast Turkey. Saudi Med J. 2006; 27(5): 61720. 